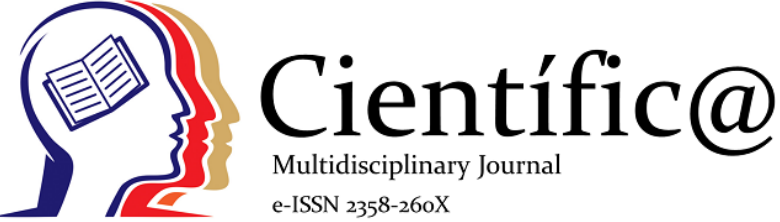

\section{Resistance To Penetration In Soil Cultivated With Sugarcane In Different Management Systems}

\author{
Resistência à Penetração Em Solo Cultivado Com Cana-De-Açúcar Em Diferentes Sistemas De \\ Manejo
}

Wagner Gonçalves Vieira Junior ${ }^{1}$, Diogo Jânio de Carvalho Matos ${ }^{1}$, Jadson Belem de Moura ${ }^{2 *}$, Rodrigo Fernandes de Souza ${ }^{2}$, Júlio Cesar Silva ${ }^{1}$, Elivan Cesar Viera Rocha ${ }^{1}$, Leidiane dos Santos Lucas $^{1}$

${ }^{1}$ Acadêmico curso de Agronomia, Faculdade Evangélica de Goianésia

${ }^{2}$ Professor Agronomia, Faculdade Evangélica de Goianésia - jadsonbelem@gmail.com

\section{Info}

Recebido: $22 / 06 / 2018$

Publicado: $14 / 11 / 2018$

DOI: 10.29247/2358-260X.2018v5i3.p161-173

ISSN: 2358-260X

\section{Palavras-Chave}

Saccharum officinarum, Compactação,

Irrigação.

Keywords:

Saccharum officinarum, Compaction, Irrigation

\section{Resumo}

A cana-de-açúcar tem sua produtividade influenciada pela disponibilidade de água e de nutrientes. Sendo o entendimento da influência do sistema de irrigação ao longo do tempo sobre a compactação do solo, importante para o aprimoramento do manejo adotado na produção desta cultura. 0 objetivo deste trabalho foi avaliar a influência do efeito dos três sistemas de irrigação, pivô e carretel, sequeiro, e carretel, sobre a resistência à penetração de raízes da cultura da cana-de-açúcar, em um período de seis anos. 0 trabalho foi realizado em condições de campo, no delineamento experimental de esquema fatorial 3 × 6 em 24 repetições, em que o primeiro fator consiste em 3 sistemas de irrigação: carretel convencional (água limpa); pivô e carretel (fertirrigação); e área de cultivo sob sequeiro. E o segundo composto por diferentes períodos sob irrigação: Área de cana-planta, área de segundo corte, área de terceiro corte, área de quarto corte, área de quinto corte, chegando ao sexto corte. Foi utilizado um penetrômetro para determinar a resistência à penetração de raízes. Ao findar desse processo de experimentação, os resultados obtidos demonstraram que utilização do sistema de irrigação pivô e carretel é o que menos afeta a resistência à penetração do solo, sendo o mais indicado para utilização.

\section{Abstract}

Sugarcane has its productivity influenced by the availability of water and nutrients. Being the understanding of the influence of the irrigation system over time on soil compaction is important for the improvement of the management adopted in the production of this crop. The objective of this paper was to evaluate the influence of the three irrigation systems: pivot and reel, reainfed, and reel, on the resistance to root penetration of the sugarcane crop, in a period of six years. The work was carried out under field conditions, in the experimental design of a $3 \times 6$ factorial scheme in 24 replicates, in which the first factor consists of three irrigation systems: conventional (clean water) reel; pivot and reel (fertigation); and rainfed cultivation. And the second factor is related to different periods under irrigation: Cane-plant area, second cut area, third cut area, fourth cut area, fifth cut area, reaching the sixth cut. A penetrometer was used to determine the resistance to root penetration. At the end of this experiment, the results showed that the use of the pivot and reel irrigation system is the one that least affects the resistance to soil penetration, being the most suitable for use. 


\section{INTRODUCTION}

Saccharum officinarum sugarcane culture was one of the first crops introduced in the country (in Brazil) for profit (LUCCHESI, 1995). The agroindustry of this culture exerts a strong socioeconomic influence, being the largest generator of direct and indirect jobs, besides generating considerable economic and cultural values. According to Lucchesi (1995), this is due to, in part, its wide range of use, being used as raw material in the production of sugar and anhydrous alcohol, in the manufacture of rapadura, molasses, "aguardente" (entre aspas) and fertilizers, in the production of energy and paper from bagasse, animal feed as hay or supplementation of animal feed from vinasse.

Currently, Brazil is the largest producer of sugarcane in the world, and the current price of fossil fuels in Brazil and the growing use of hybrid vehicles is what leads the national alcohol program. In this scenario, the state of Goiás has been outstanding in the production and expansion of cultivation area. Since 2003, the energy matrixes used by Brazil are considered to be one of the cleanest in the world, and about $47 \%$ of the energy produced can be considered sustainable, of which $18 \%$ come from the production of sugarcane (KOHLHEPP , 2010).

In Goiás, sugarcane is industrially grown in more than 193 cities. Of these, the South and Central regions account for $95.3 \%$ of the state's production. Generally, up to the 2010 harvest, sugarcane accounted for approximately $12.8 \%$ of the state's total agricultural production, representing a 315.8\% growth in area planted between 2000 and 2010 (SILVA, 2013).
The economic importance of this crop to the state is undeniable, especially for the municipality of Goianésia, which has three large mills: Jalles Machado Plant, Otávio Lage Unit and Goianésia Plant.

It is known that one of the main factors that can influence the increase of crop productivity is the availability of water and nutrients. But water from the rains, in most situations. cannot meet the real water requirement of the crop, and thus, irrigation becomes important to supply the needs of the plant. This practice, when well planned, has an unquestionable economic return (AZEVEDO, 2002).

In contrast, soil compaction is seen as a form of degradation that impacts the structure and productive capacity of soils. This process, affects negatively the physical, chemical and biological properties, and causes losses to the growth of the roots of the plants, decreasing the productivity (MOSSADEGHI-BJÖRKLUND et al., 2016).

To get an idea of what happens, solid particles of soil, when under pressure, can be rearranged, leading to compaction and destruction of soil aggregates. The intensity of this process depends on the amount of soil water and the external pressure applied to the soil by the management systems adopted (BRAVO et al., 2016).

Therefore, the understanding of the influence of the irrigation system over time on soil compaction is so important for the improvement of the management adopted in the production of this crop. This phenomenon is impossible to 
avoid, it can only be mitigated, and it is fundamental to elucidate techniques that minimize the negative impact of management practices. The delimitation of performance parameters can help decision making about what management that should be adopted (REICHERT et al, 2007).

Irrigation aims to provide water to supply all the water needs of plants. It is an old technique, which has been perfected over the centuries. At present, there are efficient systems such as central pivot, self-propelled and fertirrigation in which water is dripped at the time, place and correct quantity for the efficient development of plants.

According to Zocoler et al., (2012), the central pivot is one of the methods of irrigation, in which progress has been made in the propulsion, alignment and water distribution devices. These changes allowed to reduce energy consumption without affecting the uniformity and efficiency of water application.

The self-propelled (also called reel) is a mechanism for irrigation of medium areas, between 08 and 64 ha. It is composed of a hydraulic-type sprinkler, mounted on a trolley that moves by hydraulic reaction, guided by a steel cable or by its hose. Thus, the reel irrigates one strip of land at a time, moving from one end to the other (RICHTER, 2015).

Fertigation is a method that consists of fertilization through irrigation water. For crops, it is considered the most efficient form of fertilization because it can provide the combination of water and nutrients, which as well as sunlight are the factors considered most relevant so that the plants can complete their development and thus obtain a good production. Thus, the irrigation systems considered to be more efficient to perform the fertirrigation are the pressurized ones, because the distribution of nutrients in a uniform way is directly related to the coefficient of uniformity of water irrigation (TRANI; TIVELLI; CARRIJO, 2011).

It should also be noted that the width of the wheelsets, influences the high pressure per axle and the traffic in newly revolved areas and can intensify the soil compaction. This behavior is aggravated when the soil is managed with an inadequate amount of water for the transit of agricultural machines (SILVA et al., 2006). In the handling of sugarcane, there is an intense traffic of heavy vehicles, which causes soil compaction. The choice of vehicles that can carry a greater load is made to lower the costs of operations. However, the traffic of these vehicles in soils considered unfavorable in relation to their water content, makes compacting of the soil something almost inevitable.

(MOSSADEGHIBJÖRKLUND et al., 2007).

What is perceived with this process is that the productivity of the sugarcane is impaired by the compaction of the soil, because the compaction reduces the absorption of nutrients in the plants what affects its development. The production of stem and leaf biomass is directly affected by soil compaction (Bonelli et al., 2011).

It is important to note that tests with sugarcane varieties on soils under different compaction levels verified a reduction of the concentration of $\mathrm{Zn}, \mathrm{B}$ and $\mathrm{Fe}$ in the aerial part

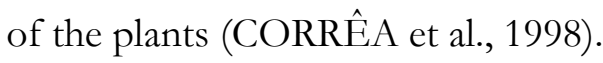


The objective of this study was to evaluate the effect of those three irrigation systems on the resistance to root penetration of the sugarcane crop in a period of six years, increasing the longevity and productivity of sugarcane plantations.

\section{MATERIALS AND METHODS.}

The research was carried out under field conditions, in the commercial sugarcane growing area of the Otávio Lage Power Plant, in the second half of the year of 2016, located in the city of Goianésia, in the state of Goiás. The predominant soil in the region is classified as Latossol. The climate is classified according to Koppen (1931) as seasonal tropical (Aw), characterized by two well defined seasons (dry and rainy), as well as the occurrence of drought periods during the rainy season.

The experimental design was completely randomized in a $3 \times 6$ factorial scheme in 24 replications, in which the first factor consists of three irrigation systems: conventional reel (clean water); pivot and reel (fertigation); and reainfed.
The second factor was composed of different periods under irrigation: cane-plant area, second cut area, third cut area, fourth cut area, fifth cut area, reaching the sixth cut. In order to determine the resistance to root penetration, the IAA / PLANALSULCAR impact penetrometer (STOLF, 1983) was used, with a fine tip, between 0-60 $\mathrm{cm}$ depths in each plot. Each replicate was composed of 3 samples, being 2 in the planting line and 1 in the line, randomly in the extension of the plot.

The penetration resistance data were obtained in numbers of impacts $\mathrm{dm}-1$, being transformed in $\mathrm{kgf} \mathrm{cm}-2$ through the equation $\mathrm{R}$ $(\mathrm{kgf} \mathrm{cm} 2)=5.6+6.98 \mathrm{~N}($ STOLF et al., 1983) Subsequently, these values were multiplied by the constant 0.098 for transformation into MPa units according to Arshad et al, (1996). Root penetration resistance values were interpreted according to Table 1 , in which the penetration resistance (RP) classes adapted from the Soil Survey Staff (1993) are presented, and the transformed data for classification by interval of 5 centimeters according to the methodology proposed by Stolf et al (2014).

Table 1 Class soil resistance to penetration of roots (MPa)

\begin{tabular}{lc}
\hline Class & Resistance to root penetration (MPa) \\
\hline Extremely low & $<0,01$ \\
Very low & $0,01-0,1$ \\
Low & $0,1-1,0$ \\
Moderate & $1,0-2,0$ \\
High & $2,0-4,0$ \\
Very high & $4,0-8,0$ \\
Extremely high & $>8,0$ \\
\hline
\end{tabular}

Adapted from Soil Survey Staff (1993) por Ashad et. al. (1996).

\section{RESULTS AND DISCUSSIONS}

When comparing PR (resistance to penetration) in cane fields under sow irrigation
(Figure 1) the $0-20 \mathrm{~cm}$ and $20-40 \mathrm{~cm}$ layers in the first year presented very high PR (5 MPa). The 40-60 cm RP layer was classified as high (3 MPa). 
These data demonstrate that the conventional

reel irrigation system presents lower rates of soil

compaction for the first agricultural year.

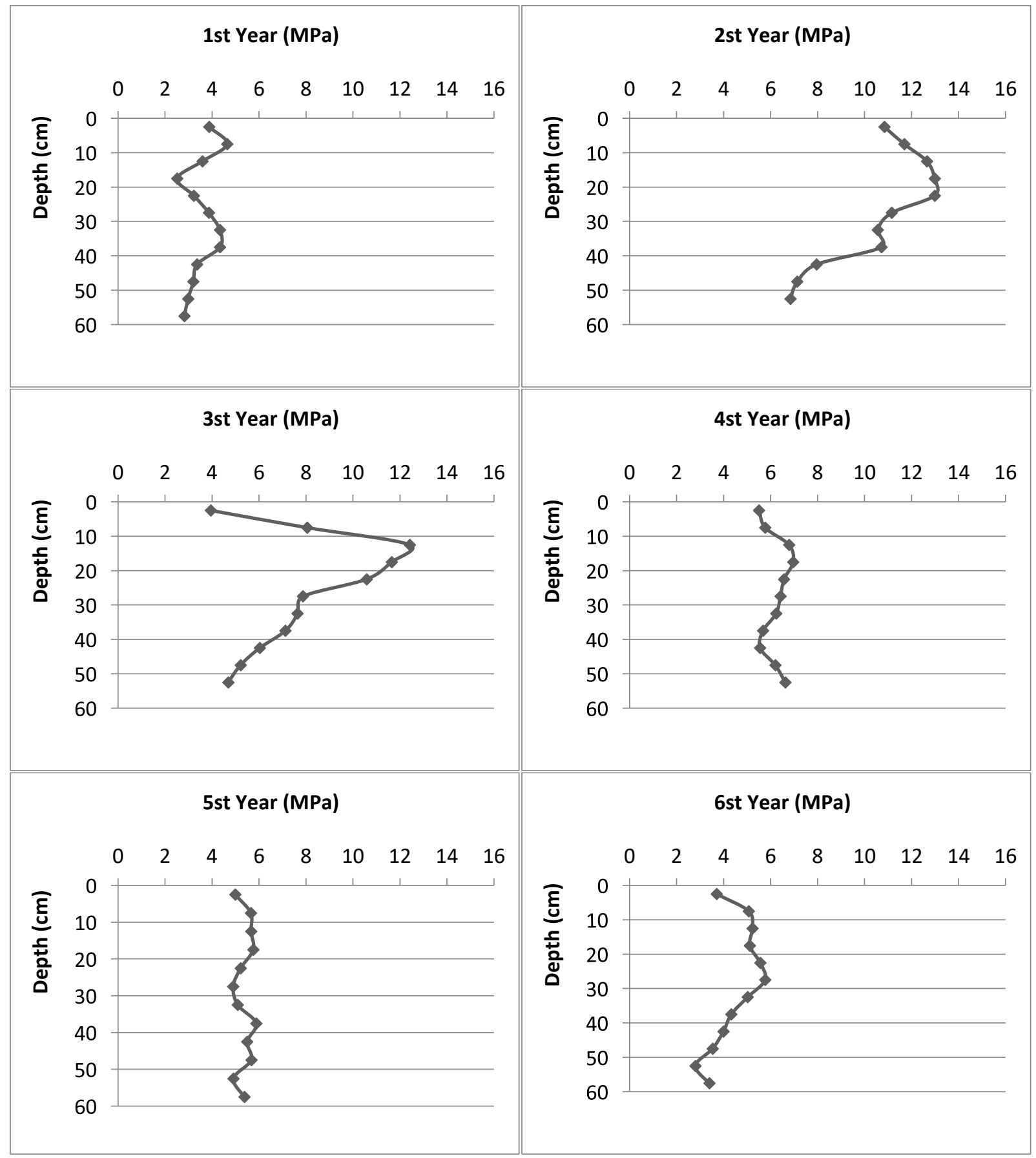

Figure 1 Compaction of the soil in areas with conventional reel irrigation in sugarcane crops over six years

In the second year, the layers of $0-20 \mathrm{~cm}$ and $20-40 \mathrm{~cm}$ showed an increase in RP compared to the first year, of very high in both layers $(5 \mathrm{MPa})$, to extremely high (13MPa). PR at 40-60 cm was considered very high (8 M Pa). 
There were no changes in RP in the 0 - 20 $\mathrm{cm}$ layer and $40-60 \mathrm{~cm}$ in the second to the third year. In the bed of the $20-40 \mathrm{~cm}$ there was a reduction of the PR from extremely high to very high.

From the fourth year to the sixth year, in all layers the PR was classified as very high, with no differences between the layers of the soil.

That can be explained by the lower traffic of machines in the area, because it was plant cane. According to Vasconcelos and Garcia (2005), the increase in soil density occurs simultaneously with the reduction of macroporosity, reduction of aeration, reduction of hydraulic and gas conductivity and increase of the resistance to penetration. Being that one of the attributes that interferes the most in the root development is the density of the soil. This density can increase in values, due to the resulting compaction of pressures exerted by the traffic of machines, vehicles, implements and animals.

According to Lima et al., (2009), besides the pressure exerted by the machines, soil moisture at the moment of operations also acts as an important factor in the distribution of compaction in the profile, and the degree of detrimental effects depends on the proportions of clay, silt and sand of different soil classes.
The data found corroborate with Pacheco's (2011) statement, which verified the increase of soil compaction in long-term crops. Similar results were found in all treatments evaluated.

The values of resistance to soil penetration in the pivot and reel irrigation system over six years, with a depth of $0-60 \mathrm{~cm}$ from the soil are presented (Figure 2).

In the first year, in the layer $0-20 \mathrm{~cm}$ of depth, presented a RP classified as high $(4 \mathrm{MPa})$. The layers of $20-40 \mathrm{~cm}$ and $40-60 \mathrm{~cm}$ depth presented RP rated very high.

In the second year, at all depths RP was classified as very high. In the third year of cultivation, the PR in all depths investigated was classified as high.

In the fourth year RP at depth of $0-20 \mathrm{~cm}$ was classified as high extremity (13 $\mathrm{MPa})$. In the other analyzed depths of this year, RP was classified as very high. In the fifth and sixth year, in the depths of $0-20 \mathrm{~cm}$ and 20 and $40 \mathrm{~cm}$, RP was classified as very high. In the layer of $40-60$ $\mathrm{cm}$ of depth was observed a reduction in RP values of very high, found in the upper layers, for high. 


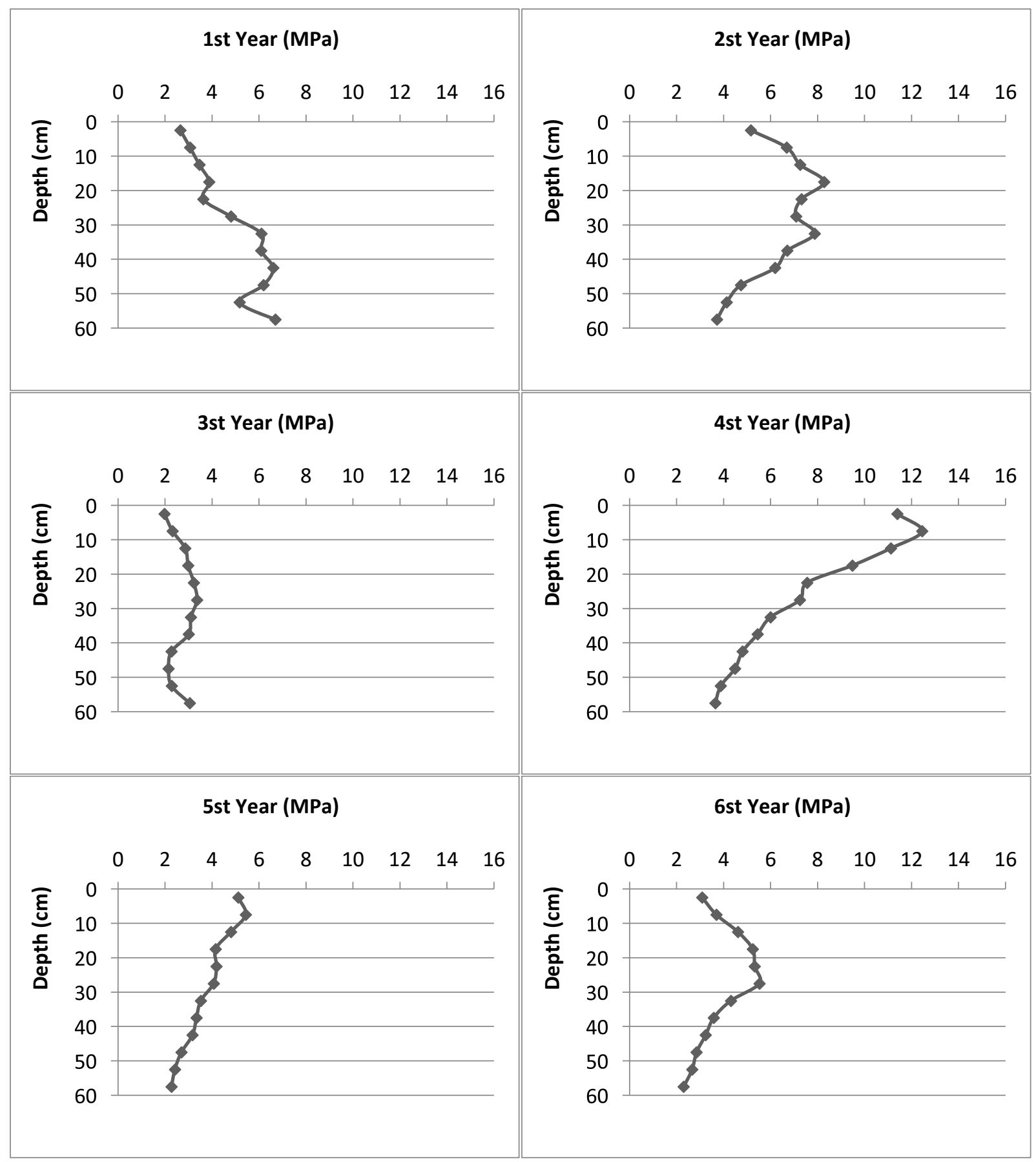

Figure 2 Soil compaction in areas with pivot and reel irrigation in sugarcane over six years

Tavares et al. (2011) found that soil wetting reduced penetration resistance by not limiting the root growth of the studied soil, results observed in the treatment of pivot and reel irrigation.

Through this observation, the mechanical decompression is recommended with the use of a subsoiler and / or scarifier, in the appropriate depth; incorporation of organic matter and / or soil cover; use of green fertilizer species interspersed with the commercial crop; and, where possible, in the case of annual crops, make use of the practice of crop rotation (SILVA et al., 2007).

Practices such as subsoiling with plowing and harrowing increase the porosity of the soil surface layer as well as the potential for root development. (CORSINI and FERRAUDO, 1999). According to COLLARES et al. (2008), soil 
scarification is very effective in reducing the effects of soil compaction, mainly in the reduction of resistance to penetration.

are found in figure 3 .
The values of RP in sugarcane under a rainfed system over six years of cultivation

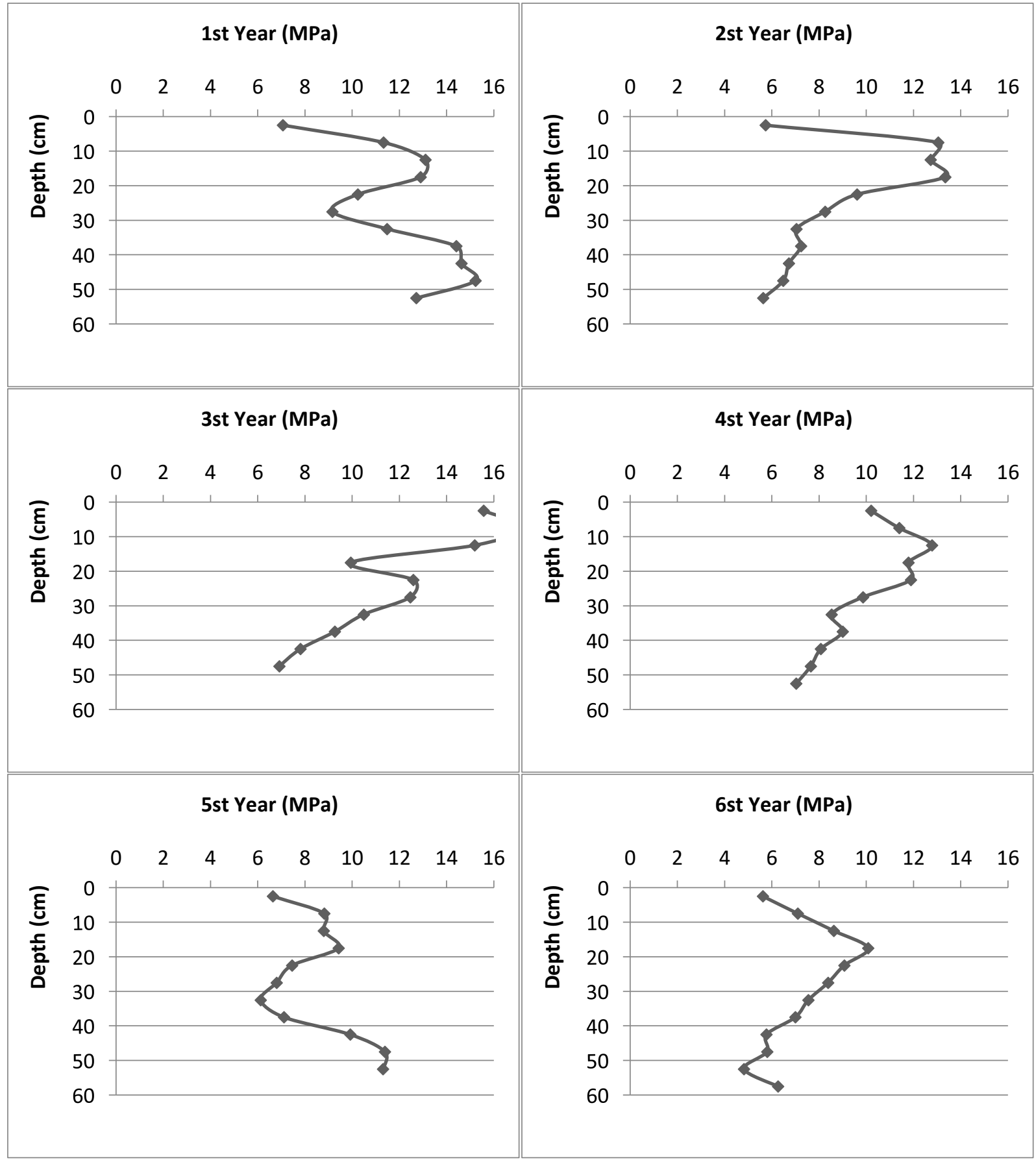

Figure 3 Soil compaction in rainfed areas in sugarcane over six years

The values of PR in the first, second, third and fourth years, in the depths of $0-20 \mathrm{~cm}$ and 20 $40 \mathrm{~cm}$ were classified as extremely high, and the depth of 40-60 cm showed a very high PR. In the fifth and sixth years of cultivation, extremely high $\mathrm{RP}$ was found in all depths investigated.

The presence of water is a determining factor in soil compaction resistance levels. In 
researches developed in Argissolos, Pacheco (2011) found a positive correlation between water levels in soil and the increase of PR in sugarcane cultivated under rainfed conditions.

In these processes, the decomposition can be done through the addition of organic matter and operations such as plowing, harvesting, or scarification, since the compacted layer only comprises the first $10 \mathrm{~cm}$ of the soil (LIMA et al., 2009).

Therefore, it is proven that, greater soil water retention resulting from compaction does not mean greater availability of water to the plant (LIMA et al., 2009).

It is worth mentioning that the mechanical resistance of the soil to root penetration causes increases in the results of the interaction between the decrease in the volume of gravimetric water and the increase in soil density. Very high values of soil resistance to penetration can influence root growth in length and diameter. Soil resistance to penetration influences the growth of roots and shoot. (MEROT'TO JUNIOR, MUNDSTOCK., 1999).

Thus, with the increase of the resistance of the soil in the superficial layer, the roots can not develop in the soil profile. The root, upon finding a zone of impediment, performs the emission of hormonal signals to emit the growth of the aerial part. Then, occurs the excessive sprouting of lateral roots eecurs in a small volume of the soil, which may lead to malnutrition, tipping and water deficit. With this, the plants start to spend extra energy to survive. So, the mechanical resistance to penetration compromises productivity by reducing or preventing the growth of the root system and, consequently, of the aerial part of the plants (PEDROTTI et al., 2001).

It is verified from this process that, soil compaction is considered as a limiting factor for increasing sugarcane productivity, causing a change in soil porosity and reducing the amount of available water by up to $100 \%$. This leads to a decrease in crop productivity and soil environmental degradation (SOUZA; LAMBERT, 2016).

When compared to irrigation with reel and, pivot and reel, over the 6 years (figure 4). RP was classified as very high. The soil under rainfall in the $0-20 \mathrm{~cm}$ layer shows RP of $12 \mathrm{MPa}$, classified as extremely high.

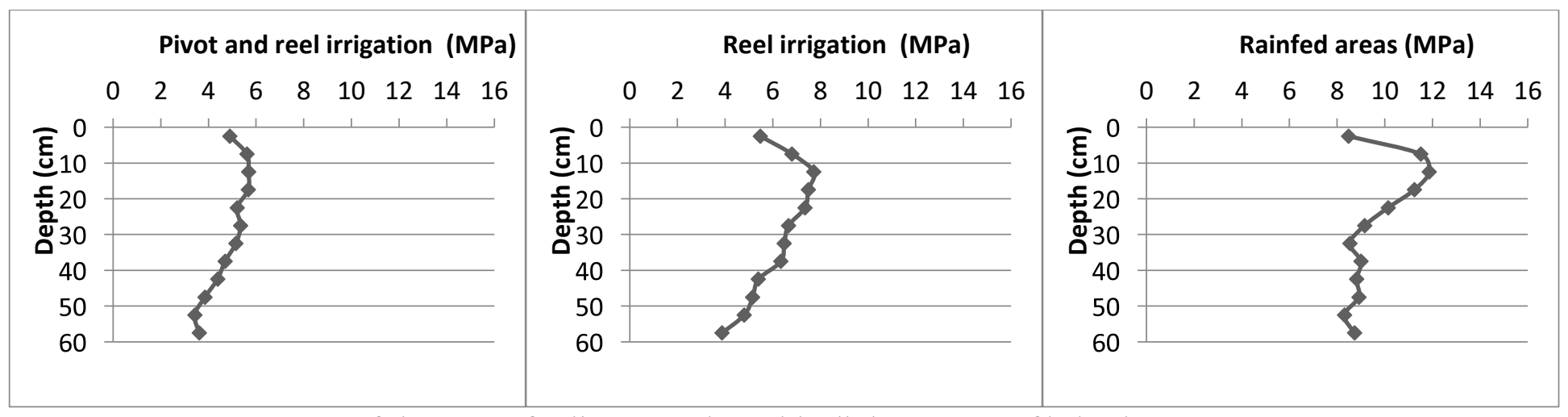

Figure 4 Average of six years of soil compaction with all three types of irrigation 
In all treatments, the $10-20 \mathrm{~cm}$ layer was the one with the highest PR, but the impact is different in each irrigation system, and the rainfed treatment has a penetration resistance peak twice higher than that of pivot and reel. And the reel treatment has intermediate behavior in relation to the resistance to penetration. However, FRANCETTO et al. (2014) says that the traffic of machines causes changes in the physical conditions of the soil, providing reduction of total porosity and increase of soil density. In this way, continuous traffic increases compression.

The 50-60 layers are those with the lowest RP. These results corroborate with those found by Carvalho et al. (2012), which evaluated the mechanical strength of the soil at depths of $0-10$ and $0-50 \mathrm{~cm}$, observed that the deeper layers presented lower PR values.

Results indicate that in the rainfed area under no-tillage, up to depth $0,4 \mathrm{~m}$, impediments to root penetration may occur during periods of water deficit (KLEIN; LIBARDI; SILVA, 1999). According to Costa (2005), morphological alterations in roots can occur due to variations in resistance to penetration.

Souza et al. (2006), discusses that the water content affects the spatial variability of soil resistance. In the wetter soil conditions, soil penetration resistance values can be considered as not impeditive to root growth, the highest values of soil resistance to penetration were detected closer to the limit of soil contraction. (Assis et al., 2009).

According to Blainski et al. (2008), in compacted soils, physical quality control is dependent on water availability. And the reduction of PR by methods that increase the porosity through reduction of soil density is an alternative to maintain the PR in non-impeditive levels to the plants.

\section{CONCLUSION}

The use of the pivot and reel irrigation system (fertigation) is what least affects the resistance to soil penetration, being the most suitable for use.

The resistance to penetration has a cumulative effect with the course of the cultivation in sugarcane.

Soil moisture differed the irrigation management systems when compared to rainfed soil.

\section{REFERENCES}

ASSIS, R, I.; LAZARINI, G. D.; LANÇAS, K. P.; FILHO, A. C. Avaliação da resistência do solo à penetração em diferentes solos com a variação do teor de água. V. 29, p. 558 - 568. 2009.

ARSHAD, M. A.; LOWERY, B. \& GROSSMAN, B. Physical tests for monitoring soil quality. In: DORAN, J.W. \& JONES, A.J., eds. Methods for assessing soil quality. Madison, Soil Science Society of America. 1996. p. 123-141 (SSSA Special publication 49).

AZEVEDO, H. M. Resposta da cana-deaçúcar a níveis de irrigação e de adubação de cobertura nos tabuleiros da Paraíba. Campina Grande: UFCG, 2002.

BLAINSKI, É.; RIBON, A. A. ; FERNANDES, K. L.; SILVA, O. C. C.; OLIVEIRA, L. C.; SILVA, A. A. Quantificação da degradação física do solo por meio da curva de resistência do solo à penetração. Revista Brasileira de Ciência do Solo, Viçosa, v. 32, n. 3, p.975-983, jun. 2008. Disponível em:

$<$ http://www.scielo.br/scielo.php?script $=$ s 
ci_arttext\&pid $=\mathrm{S} 0100$ -

06832008000300007>. Acesso em: 25 nov. 2016.

BONELLI, E. A.; BONFIM-SILVA, E. M.; CABRAL, C. E. A.; CAMPOS, J. J. SCARAMUZZA, W.L.M.; POLIZEL, A.C. Compactação do solo: Efeitos nas características produtivas e morfológicas dos capins Piatã e Mombaça. Revista Brasileira de Engenharia Agrícola e Ambiental, v.15, n.3, p.264-269. 2011.

BRAGA, M. B.; CALGARO, M. Sistema de Produção de Melancia: Irrigação. 2010. Disponível em:

$<$ https://sistemasdeproducao.cnptia.embra pa.br/FontesHTML/Melancia/SistemaPro ducaoMelancia/irrigacao.htm>. Acesso em: 30 maio 2016.

BRAVO, E. L., SUÁREZ, M. H., CUETO, O. G., CORONEL, C. I., RAMON, H. Effect of Moisture and Soil Compaction on Tillage Operations. Revista Ciências Técnicas Agropecuárias, v. 25, n. 1, p. 32-37, 2016.

CARVALHO, A. P. V.; DIAS, H. C. T.; PAIVA, H. N.; TONELLO, K. C. Resistência mecânica do solo à penetração na bacia hidrográfica do Riacho Fundo, FelixlândiaMG. Revista Árvore, Viçosa, v. 36, n. 6, p.1091-1098, dez. 2012. Disponível em: $<$ http://www.scielo.br/scielo.php?script $=$ s ci_arttext\&pid $=$ S0100 -

67622012000600010>. Acesso em: 25 nov. 2016.

COLLARES, G. L.; DALVAN, J. R.; REICHERT, J. M.; KAISER, D. R.; Compactação de um Latossolo induzida pelo tráfego de máquinas e sua relação e sua relação com o crescimento e produtividade de feijão e trigo. Revista Brasileira de Ciência do Solo. 32:933-942, 2008.

CONSINI, P. C.; FERRAUDO, A. S.; Efeitos de sistemas de cultivo na densidade e macroporosidade do solo e no desenvolvimento radicular do milho em Latossolo roxo. Pesquisa Agropecuária Brasileira. Brasília, v.34, n2, p289-298, fev. 1999.
COSTA, M. C. G. Distribuição e crescimento radicular em soqueiras de cana-deaçúcar: dois cultivares em solos com características distintas. 2005. $104 \mathrm{f}$. Monografia (Especialização) - Curso de Agronomia, Escola Superior de Agricultura "Luiz de Queiroz", Piracicaba, 2005.

CORREAA, J. B. D.; ANDRADE, L. A.; DIAS JUNIOR, M. S.; ALVES, V. G. E Efeito da compactação na concentração foliar de nutrientes na cana-de-açúcar em três tipos de solos. In: FERTIBIO, 1998, Lavras. Anais...Lavras, MG: UFLA \SBPC \SBM, 1998. p. 91.

FRANCETTO, T. R.; LEINDECKER, J. A.; DAGIOS, R. F.; OLIVEIRA, Z. B. DE. Tráfego de máquinas agrícolas $\mathrm{e}$ alterações na densidade do solo e porosidade total de um Argissolo vermelho em área sob videira. XLIII Congresso Brasileiro da Engenharia Agrícola- CONBEA, Campo Grande- MS, 27 a 31, jul. 2014.

KLEIN, V. A.; LIBARDI, P. L.; SILVA, A. P. Resistência do solo à penetração sob diferentes condições de umidade e manejo. In: congresso brasileiro de engenharia agrícola, 27, 1999, Guaíra. Resumo expandido. Pelotas: CONBEA, 1999. p. 1 $-16$.

KOHLHEPP, Gerd. Análise da situação da produção de etanol e biodiesel no Brasil. Estudos Avançados, São Paulo, v. 24, n. 68, p.223-253, jan. 2010.

KOPPEN, W. P. Grundriss der klimakunde. 1931.

LIMA, R. P.; LEON, M. J.; GONZAGA, B. A. B. S.; SANTOS, R. F. Resistência a Penetração e Densidade do Solo como Indicativos de Compactação do Solo em Área de Cultivo da Cana-de-Açúcar. In: Congresso brasileiro de ciência do solo: o solo e a produção de bioenergia perspectivas e desafios, 32, 2009, Areia. Fortaleza: CBCS, 2009. p. 1 - 5. 


\section{LUCCHESI, A. Processos fisiológicos da} cultura da cana-de-açúcar (Saccharum spp). Piracicaba: ESALQ/USP, 1995.

MEROTTO JUNIOR, A.; MUNDSTOCK, C. M. Wheat root growth as affected by soil strength. Revista Brasileira de Ciência do Solo, Viçosa, v. 23, n. 2, p.197-202, jun. 1999. Disponível em: $<$ http://www.scielo.br/scielo.php?script $=\mathrm{s}$ ci_arttext\&pid $=$ S0100-

06831999000200002>. Acesso em: 24 nov. 2016.

MOSSADEGHI-BJÖRKLUND, M.; ARVIDSSON, J.; KELLER, T.; KOESTEL, J.; LAMANDÉ, M.; LARSBO, M.; JARVIS, N. Effects of subsoil compaction on hydraulic properties and preferential flow in a Swedish clay soil. Soil and Tillage Research, v. 156, p. 91-98, 2016.

PACHECO, E. P.; CANTALICE, J. R. B. Compressibilidade, resistência a penetração e intervalo hídrico ótimo de um Argissolo Amarelo cultivado com cana-de-açúcar nos Tabuleiros Costeiros de Alagoas. Revista Brasileira de Ciência do Solo, v. 35, n. 2, p. 403-415, 2011.

PEDROTTI, A.; PAULETTO, E. A.; CRESTANA, S.; FERREIRA, M. M.; DIAS JUNIOR, M. S.; GOMES, A. S.;

TURATTI, A. L. Resistência mecânica à penetração de um Planossolo submetido a diferentes sistemas de cultivo Revista Brasileira de Ciência do Solo, Viçosa, v. 25, n. 3, p.521-529, set. 2001. Disponível em:

$<$ http://www.scielo.br/scielo.php?script $=$ s ci_arttext\&pid $=$ S0100 -

06832001000300001>. Acesso em: 24 nov. 2016.

REICHERT, J. M.; SUZUKI, L. E. A. S.; REINERT, D. J. Compactação do solo em sistemas agropecuários e florestais: Identificação, efeitos, limites críticos e mitigação In: CERRETA, C. A.; SILVA, L. S.; REICHERT, J. M. Tópicos em ciência do solo. Viçosa, MG, Sociedade Brasileira de Ciência do Solo, 2007.v.5. p. 49-134.
RICHTER, L. A. IRRIGAÇÃO DE

PASTAGENS. In: CORDEIRO, L. A. M. et al. Integração lavoura-pecuária-

floresta: o produtor pergunta, a Embrapa responde. Brasília: Embrapa, 2015. p. 489507. Disponível em:

<http://www.cnpt.embrapa.br/biblio/li/li 01-forrageiras/cap17.pdf>. Acesso em: 12 jun. 2016.

SILVA, A. C.; SILVA, A. C.; WENNINGKAMP, K. R.; TOMÉ, L. H. P.; SHIKIDA, P. F. A.; PIACENTI, C. A. Determinantes do crescimento do valor bruto da produção de cana-de-açúcar no centro-oeste do Brasil. Pesquisa \& Debate. Revista do Programa de Estudos Pós-Graduados em Economia Política. ISSN 1806-9029, v. 24, n. 2 (44), 2013.

SILVA, A. J. N.; CABEDA, M. S. V. Compactação e compressibilidade do solo sob sistemas de manejo e níveis de umidade. Revista Brasileira de Ciências do Solo, Viçosa , v. 30, n. 6, p. 921-930, Dec. 2006 . Available from $<$ http://dx.doi.org/10.1590/S010006832006000600001>. Acesso em : 18 Fev. 2006.

SILVA, M. S. L.; CHAVES, V. C.; CAVALCANTI, A. C.; NETO, M. B. O.; SANTOS, J. .P.; MENDES, A. M. S.; ANJOS, J. B. Adensamento e compactação de solos irrigáveis da zona semi-árida do Nordeste brasileiro. Recife: Embrapa, 2007. 8 p. Disponível em: <http://ainfo.cnptia.embrapa.br/digital/bit stream/item/32330/1/Alessandra.pdf $>$. Acesso em: 20 nov. 2016.

SOUZA, M. T.; LAMBERT, R. A. Avaliação de compactação do solo na cana-de-açúcar utilizando penetrômetro. Enciclopédia Biosfera, Goiânia, v. 13, n. 23, p.138-147, 20 jun. 2016. Disponível em: <http://www.conhecer.org.br/enciclop/20 16a/agrarias/avaliacao de compactacao.pdf $>$. Acesso em: 24 nov. 2016. 
SOUZA, Z. M.; CAMPOS, C. C.M.;

CALVALCANTE, I. H. L.; JÚNIOR, J. M.; CESARIM, G. L.; SOUZA, S. R.

Dependência espacial da resistência do solo à penetração e do teor de água do solo sob cultivo contínuo de Cana-de-açúcar. V. 36, n 1, p $128-134,2006$.

STOLF, R.; MURAKAMI, J. H.; BRUGNARO, C.; SILVA, L. G.; SILVA, L. C. F.; MARGARIDO, L. A. C. Penetrômetro de impacto stolf-programa computacional de dados em Excel-VBA. Revista Brasileira de Ciência do Solo, v. 38, n. 3, p. 774-782, 2014.

TAVARES, U. E.; MONTENEGRO, A. A. A.; ROLIM, M. M.; SILVA, J. S.; VICENTE, T. F. S.; ANDRADE, C. W. L. Variabilidade espacial da resistência à penetração e da umidade do solo em Neossolo Flúvico. Water Resources And Irrigation Management, [S.l.], v. 3, n. 2, p.79-89, 30 ago. 2014. Disponível em: $<$ http://www.bibliotekevirtual.org/index.p hp/2013-02-07-03-02-35/2013-02-07-0303-11/1473-wrim/v03n02/15051variabilidade-espacial-da-resistencia-apenetracao-e-da-umidade-do-solo-emneossolo-fluvico.html>. Acesso em: 11 nov. 2016.
TRANI, P. E.; TIVELLI, S. W.; CARRIJO, O.

A. Fertirrigação em hortaliças. Campinas: Instituto Agronômico, 2011. 58 p.

Disponível em:

<http://www.iac.sp.gov.br/publicacoes/po rassunto/pdf/BT_196_FINAL.pdf>.

Acesso em: 08 jun. 2016.

VASCONCELOS, A. C. M.; GARCIA, J. C. Cana-de-açúcar: ambientes de produção. [S.I]: Embrapa, 2005. 5 p.

Disponível em:

$<$ https://www.agencia.cnptia.embrapa.br/ Repositorio/Encarte110_desenvolvimento_ radicular_000fizw8owz02wyiv802hvm3jdeq c1jc.pdf>. Acesso em: 19 nov. 2016.

ZOCOLER, J. L.; LIMA, A. S.; HERNANDEZ, F. B. T.; MAGGI, M. F.; YANO, E. H. Eficiência de aplicação da irrigação em pivô central utilizando inversor de frequência no sistema de bombeamento. In: congresso nacional de irrigação e drenagem, Não use números Romanos ou letras, use somente números Arábicos., 2012, Cascavel. Anais... . Cascavel: Conird, 2012. p. 1 - 7.

Disponível em:

$<$ http://www.agr.feis.unesp.br/pdf/Conird _2012/artigos_novos/eficiencia_pivo_zoco ler_CONIRD2012.pdf>. Acesso em: 08 jun. 2016. 